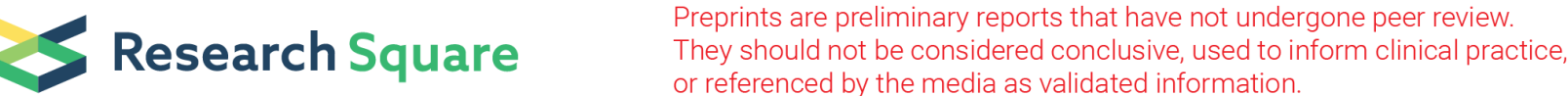

\section{Why do Older Women with Invasive Breast Cancer Avoid Surgery? A Qualitative Analysis of Factors Influencing the Decision of Patients and Physicians}

Fernando A. Angarita ( $\square$ angarita.fa@gmail.com )

University of Toronto https://orcid.org/0000-0002-8546-7309

Ethan Hoppe

University of Toronto

Gary Ko

University of Toronto

Justin Lee

University of Toronto

Danny Vesprini

University of Toronto

Nicole Look Hong

University of Toronto

\section{Research Article}

Keywords: older adult, breast cancer surgery, decision-making

Posted Date: February 8th, 2021

DOI: https://doi.org/10.21203/rs.3.rs-178701/v1

License: () (1) This work is licensed under a Creative Commons Attribution 4.0 International License.

Read Full License 


\section{Abstract}

Purpose: Limited data exists about why older women ( $\geq 70$ years old) with breast cancer avoid surgery. This study aimed to identify physician- and patient-perceived attitudes that influence the decision to avoid surgery among older women with invasive breast cancer.

Methods: Semi-structured in-depth interviews were conducted with multidisciplinary breast cancer specialists and with older women with breast cancer who declined surgery. Transcripts were iteratively coded using a theoretical framework to guide identification of common themes. Thematic comparison was performed between patients and physicians.

Results: Ten breast cancer specialists and eleven patients participated. Physicians believed older women declined surgery because they did not perceive their breast cancer as a life-threatening ailment compared to other medical comorbidities. Physicians did not discuss breast reconstruction, as it was perceived to be unimportant. Treatment side effects, length of treatment, impact on quality of life, and minimal survival benefit strongly influenced a patient's decision to decline surgery. Patients valued independence and quality of life over quantity of life. Patients felt empowered to participate in the decision-making process but appreciated having support. Both groups had congruent beliefs with respect to age impacting treatment decision, cosmesis playing a minor factor in treatment decisions, and importance of quality of life; however, they were discordant in their perceptions about the amount of support that patients have from their families.

Conclusion: The decision to avoid surgery in older women stems from a variety of individual beliefs. Acknowledging patient values early in treatment planning may facilitate a patient-centered approach to treatment decision making.

\section{Introduction}

Older women ( $\geq 70 y)$ comprise approximately one-third of newly diagnosed breast cancer patients $[1,2]$. Older women represent a unique patient population, as they often have multiple comorbidities, lower performance status, less social support, and shorter life expectancy [3-6]. Additionally, these patients often have breast cancers with favorable tumor biology (e.g. low-grade, estrogen and progesterone receptor positive, and HER2/neu negative) [7]. The optimal treatment for older women is also unclear, as they are often underrepresented in clinical trials $[8,9]$.

Some older women with breast cancer choose not to undergo surgery $[6,10,11]$, instead opting for primary endocrine therapy (PET), radiation therapy (RT), or no treatment. There are a number of reasons for this, including the high number of comorbidities, preference for less invasive procedures, desire to avoid anaesthesia, lower life expectancy, and physician's recommendation [12]. Consequently, balancing the risks of curative-intent surgery with the physical and emotional needs of the patient is challenging. 
Qualitative studies have explored patient-reported factors that influence the decision-making process of older women with breast cancer. A recent systematic review of the qualitative literature reported how treatment characteristics, personal goals, patient characteristics, physician's recommendation, and personal and family experience determined treatment choice amongst older women with breast cancer [13]. Nonetheless, these studies lacked information about physicians' perceptions. Given that some older women prefer physician-driven decision-making [14-8], it is important to compare whether patients and physicians perceive the same factors as important. Qualitative research is critical to answer this question as quantitative studies cannot describe the nuances of decision-making. An understanding of patient and physician attitudes towards surgery amongst older women may facilitate counselling and targeted educational strategies. This study aimed to identify the attitudes of physicians and patients related to avoiding surgery in older women ( $\geq 70 y$ ) with invasive breast cancer.

\section{Methods}

\section{Study design}

Institutional approval was obtained by the research ethics board at Sunnybrook Health Sciences Centre (SHSC), Toronto, ON, Canada. Figure 1 depicts the study design. A qualitative grounded therapy approach was used. One-on-one semi-structured interviews were conducted with older women ( $\geq 70 \mathrm{y})$ with invasive breast cancer who elected not to undergo surgery as initial treatment, and with multidisciplinary breast cancer specialists. Interviews were performed to examine the experiences, attitudes, decision-making strategies, and rationale for surgical avoidance.

\section{Interview question development and pilot interview study}

A systematic literature review was performed to ensure all areas of interest were addressed in the conceptual framework and question prompts for the interview [13]. Supplement 1 and 2 outline the interview guides. Pilot interviews were conducted with one patient and one physician to gauge flow and question feasibility. The data collected in these interviews were included in the final analyses. Figure 1 depicts the interview development process.

\section{Physician cohort}

Breast surgical oncologists, radiation oncologists, and medical oncologists were purposively recruited from SHSC. The following information was gathered from publicly available data on the University of Toronto and College of Physicians and Surgeons of Ontario (CPSO) website: name, email, specialty, and type of practice.

\section{Patient cohort}

The patient inclusion criteria were as follows: women age $\geq 70 \mathrm{y}$ at diagnosis, biopsy proven invasive breast cancer, stage I-III, non-surgical treatment as first attempted treatment, and English-speaking. Patient exclusion criteria included stage 0 and IV breast cancer, non-breast primary tumours, concomitant 
cancer of other origin, inability to independently speak and understand English; and inability to obtain consent.

Patients were purposively sampled from the SHSC Salvage Radiation Database, which collects data on breast cancer patients referred for ablative radiation therapy. This was an appropriate referral database for this study as institutional practice is that most women who decline upfront surgical management are offered a consultation for ablative radiotherapy. To confirm eligibility, the patient's medical record was reviewed. Initial eligibility was confirmed by reviewing their primary spoken language, mailing address, contact information, age at diagnosis of breast cancer, date of visit to clinic, clinical stage, core biopsy date and confirmation of invasive breast cancer, and initial treatment plan.

\section{Recruitment}

Participants were contacted via phone, in person, or E-mail. Participants were provided with a package including invitation letter, participation form, and consent form via mail or in person if they wanted additional information. Two weeks after initial invitation, potential participants were contacted again to follow up on their desire to participate. If the potential participant mailed the participation form indicating they would not want to enrol, they were not contacted. If the potential participant returned the participation form indicating they wanted to be enrolled, they were telephoned to set up the interview as well as to answer any questions. Ten patients and ten physicians were anticipated, with recruitment ceasing when data saturation was achieved. Interviews were performed between 2/2017 and 4/2020. The prolonged recruitment period was due to difficulty in recruiting patients.

\section{Data collection}

One-on-one semi-structured interviews were carried out either in-person or over the telephone and audiotaped on a digital recorder. Notes were taken during the interview to reflexively analyse the participant's tone of voice and body language, and to document the interviewer's own biases. The digital audio files were transcribed verbatim by a third-party transcriptionist with anonymization of all identifying information.

\section{Data analysis}

Framework analysis was performed using familiarisation, theme development, indexing, charting, and interpretation [19]. Transcripts underwent constant comparative analysis with simultaneous data collection and analysis to generate a coding schema reflecting unique ideas. Four authors analysed the interviews. Transcripts were double coded by least two authors. Similar concepts were grouped into common themes with the intent to refine an existing framework or develop a new conceptual idea to represent the understanding of ideas. Four authors independently coded the interviews and discussed results until consensus of interpretation was achieved. Patient interviews were analyzed separately from physician interviews. Common themes and frameworks between physicians and patients were compared. Data saturation was reached once repetition of conceptual ideas was observed. 


\section{Results}

\section{Physician cohort}

Twenty academic physicians were eligible for participation of which ten participated. Distribution of participants was as follows: radiation oncologists $(n=5)$, medical oncologists $(n=3)$, surgical oncologists $(n=2)$ (Figure 1). Breast cancer made up between 50 to $100 \%$ of each physician's practice. Seven physicians were female and three were male. The median years in practice was 21 [interquartile range: 7 $-30]$.

\section{Patient cohort}

Seventy-four older women were eligible for participation of which eleven participated (Figure 1). Table 1 summarizes the patient, tumor, and treatment characteristics of participants. The median age at time of breast cancer diagnosis was 84 (IQR 75-89). The majority of women were widowed $(n=5)$ followed by single $(n=2)$, married $(n=2)$, divorced $(n=1)$, and not specified $(n=1)$. Ten patients identified as Caucasian and one patient identified as Asian. Patients had a median of five comorbidities (IQR: 2-6). Three patients had a previous history of breast cancer. Previous surgeries included lumpectomy $(n=2)$, mastectomy $(n=1)$, sentinel lymph node biopsy $(n=2)$, and no lymph node procedure $(n=1)$. One woman underwent radiation therapy and all three women received hormone therapy for their previous cancers.

With respect to the presenting breast cancer, nine patients were diagnosed clinically while the other two were detected by imaging. Nine women were diagnosed with invasive ductal carcinoma while two had invasive lobular carcinoma. Ten patients had hormone receptor positive breast cancer, while one patient had triple negative breast cancer.

One patient declined all forms of treatment and ten women underwent non-surgical treatment as the initial form of therapy (eight patients opted for an aromatase inhibitor and two underwent radiation therapy alone). Of the women who sought treatment, five had changes to their treatment modalities over time. Changes to treatment were as follows: aromatase inhibitor to radiation therapy $(n=3)$, radiation therapy to aromatase inhibitor $(n=1)$, and aromatase inhibitor to tamoxifen $(n=1)$. One patient who was initially treated with aromatase inhibitor and then radiation therapy, eventually underwent a mastectomy. Patients underwent a change to treatment because of disease progression or treatment side effects.

\section{Physician qualitative results}

Table 2 summarizes and compares the physician- and patient-reported factors that influenced the decision-making process. Physicians viewed older women as a diverse group with respect to health and expectations of breast cancer treatment. Factors perceived to influence the decision-making process included treatment side effects and the length of treatment. Patient characteristics such as age and comorbidities also influenced the decision-making process. Older women were often perceived to defer treatment decisions to family members and physicians. The impact of treatment on quality of life along with the perceived minimal survival benefit were described as reasons why women declined surgery. 
Previous negative personal or family experience with surgery were also believed to affect decision making. Breast reconstruction was often not offered or not discussed in depth as it was considered unlikely to be important to older women. Additional factors that were perceived by physicians to influence treatment decision-making included lack of time for thorough assessment and treatment discussion, variable family support, impact of treatment on family dynamics, caretaker responsibilities, misinformation about the disease and treatment options, and challenges with language and cultural barriers.

\section{Patient qualitative results}

Patients reported that their treatment decisions were affected by their own previous experience as well as by the experience of other individuals. Patients valued their independence and quality of life over quantity of life when deciding on treatment. Patients were generally satisfied with their choice of non-surgical treatment. Older women felt empowered to participate in the decision-making process but appreciated having friends and family as a support. This patient population perceived their age as a factor that influenced decision making away from surgical therapy. Older women were concerned about the impact of general anesthesia on cognitive function and the extent and duration of surgery/recovery. Instead, they valued treatments that induced minimal pain or side effects. Cosmesis was not reported to be an important factor in their decision-making. Older women noted a lack of resources specific to women of their age group. They also desired more time with their physicians and information about their condition.

Decision-making varied amongst women in this study. Some women advocated strongly for their own personal values, while others preferred physician-driven recommendations. Additionally, women in this study did not appear retrospectively to struggle with decision-making. Some patients had pre-conceived ideas and rapidly evaluated and rejected or accepted treatments offered, describing an immediate preference. Other patients deliberated to varying degrees, with differing levels of external support and discussion. Healthcare professionals contributed to the process by providing an outlet to seek and receive information, providing advice about treatment options, and helping individuals to cope with the diagnosis and decision-making.

For both groups of participants, patient characteristic (e.g., age, others' experiences, and a desire to maintain independence) were perceived as key factors in decision-making. There were also several unique themes identified for physicians and patient participants. For example, patients reported a specific desire to avoid pain. While both groups felt a need for dedicated resources for older women with breast cancer, patients were satisfied with the care that they received.

\section{Conceptual theory model}

Figure 2 depicts the conceptual theory created from the thematic analysis of both physicians and patients. Factors commonly encountered in the interview analysis were synthesized. Older women with invasive breast cancer have both intrinsic and personal factors which frame their decisions. Modifiable factors within a patient's life as well as the health care system influence the decision-making process. 


\section{Discussion}

In this study, we performed a qualitative analysis to determine why older women with invasive breast cancer choose non-operative management. Treatment side effects, length of treatment, impact on quality of life, and minimal survival benefit strongly influenced women's decisions to decline surgery. In addition, patients expressed that experience (both personal and from other patients), fear of general anesthesia, and a desire to maintain independence were important factors in treatment decision-making. Physicians reported that older women declined treatment because they did not perceive their cancer as lifethreatening compared to other comorbidities. Breast reconstruction was often not discussed as it was considered unimportant to patients. Patients felt empowered to participate in the decision-making process but appreciated having support. They also valued independence and quality of life over quantity of life.

Within this study population, fear of general anesthesia was frequently reported as a reason to forego surgery. An American College of Surgeons National Surgical Quality Improvement Program study of 26,761 older women ( $\geq 70 y$ ) with invasive breast cancer showed that $88 \%$ of patients underwent surgery with general anaesthesia [25]. While the 30-day overall morbidity rate was not significantly different between young and elderly women $(3.9 \%$ versus $3.8 \%, p=0.2)$, older women did have significantly higher rates of pulmonary, cardiac, venous thromboembolic, and neurological morbidity. All-cause 30-day mortality was higher in older women compared to younger women $(0.2 \%$ versus $0.05 \%, p<0.001)$. These data suggest that perhaps alternative strategies for anesthesia should be better explored. Breast surgery can be effectively performed under local and regional anesthesia, particularly in patients who are unable to tolerate or are fearful of general anesthesia. For example, mastectomy under local anesthesia was successfully reported in a series of American Society of Anesthesiologists class IV patients [26]. This study reported no morbidity in the form of hematoma, wound infection or skin flap necrosis. A prospective observational series of patients undergoing breast conserving surgery under a paravertebral block and mild sedation reported successful outcomes, including no need for intraoperative or postoperative opioids [27]. A survey of breast surgeons noted that approximately two thirds of respondents considered breast surgery under local anesthesia to be well-tolerated amongst older women [28]. It is unknown whether patients in our study were offered alternative anesthetic strategies or would have accepted surgery if they had been offered local or regional options.

Another factor that patients frequently described as a reason to avoid surgery was the concern over the length of recovery from surgery. Most breast surgery represents a short-term inconvenience to patients, as the majority of breast surgeries are day surgeries with a minority staying one night in hospital for observation. However, the isolated short- and long-term effects of breast surgery compared to alternative treatment options on older women's functional status is unknown. Preoperative function is a well-known predictor of postoperative function. Specifically, patients who experienced preoperative functional decline are at a higher risk of accelerated postoperative functional decline [30]. Patients experiencing frailty, a multifactorial state associated with poor nutrition, strength, mobility, depression, comorbidities, and cognitive impairment, also have worse functional outcomes [31,32]. Although these patient factors 
greatly impact how well a patient recovers from surgery, the procedure itself also influences their postoperative course. Physical functional recovery in older adults who have undergone major surgery is occasionally slower compared to younger women. For example, older adults who underwent major abdominal surgery took 6 weeks to 3 months to recover basic activities of daily living, but up to 6 months to recover their instrumental activities of daily living [33]. In contrast, most older women undergoing surgery for pelvic organ prolapse, including those with low preoperative functional status, return to their baseline functional status within 3 months of surgery [34]. Unfortunately, studies looking specifically at how breast surgery affects older women's postoperative functional status are lacking. Future studies are needed to evaluate functional status after breast surgery, as the return to baseline function may be comparatively quicker compared to larger and more invasive surgery.

One of the major, but deliberate, biases in this study is that all women initially declined surgery as the primary treatment modality. It is unclear whether the patients included in this study had already decided to decline surgery prior to their surgical consultation or if patient decisions evolved over the course of actual discussions with multidisciplinary providers. However, it is clear that a fulsome discussion about the pros and cons of different treatment options is required. Non-surgical treatments such as PET) are not without difficulties. Prolonged use of endocrine therapy is associated with increased odds of developing cardiovascular disease, bone fractures, deep venous thrombosis, and endometrial cancer [35]. PET may be associated with long lasting side effects and multiple hospital visits. A disadvantage of PET is that it may be only effective for a limited period, after which the treatment must be changed, and surgery may still eventually be necessary. Additionally, adherence to PET is variable amongst older women. A systematic review reported an adherence rate of $52 \%$ to $100 \%$ amongst older women [36]. Adverse events and toxicity are generally the main reasons for discontinuation of endocrine therapy [37]. Furthermore, there are challenges when discussing the effectiveness of PET as an alternative to surgery. Trials focused on closing this knowledge gap have been met with a lack of recruitment. The British ESTEem trial was developed to compare aromatase inhibitors with surgery, but poor patient inclusion resulted in premature closure of the study. Additionally, although randomised trials comparing tamoxifen with surgery showed tamoxifen was associated with inferior local disease control but similar overall survival [38], these data have important limitations. In some of these studies, patients received tamoxifen regardless of hormone receptor status, and the quality of surgery and radiotherapy received by the surgical group may not meet modern-day standards. Aromatase inhibitors have now replaced tamoxifen in the management of breast cancer in postmenopausal women owing to proven superior efficacy in other clinical scenarios [39-42]. Given data on PET are ever evolving in this patient population, it is clear that a balanced discussion is required between patients and providers to examine the pros and cons of surgical treatments as well as non-surgical options.

Patients stressed their desire to maintain independence and quality of life over quantity of life when deciding on treatment. In a qualitative study of older women with operable breast cancer who underwent PET, patients stated their age was a marker that they were at the end of their lives [43]. While patients did not express the desire for an immediate end, they were not interested in prolonging their lives. Patients declined surgery as they were concerned about the impact of surgical therapy on their quality of their life. 
The thoughts articulated by these patients describe "a sense of completeness that life has run its course" [44]. Identifying similar points of view in patients through discussion and exploration is critical to understanding a woman's wishes surrounding breast cancer therapy. Recognizing this, health care providers can hopefully guide patients towards treatment options that most closely follow their wishes.

A challenge that lies in managing older women with breast cancer is accurately estimating life expectancy as different comorbidities having variable impact on life expectancy. Additionally, impaired cognition, malnutrition, and dependency for activities of daily living are important contributors to one's quality of life [45]. Although considered important to determine treatment options for older women with operable breast cancer [28], a recent study shows that surgeons often underestimate a patient's life expectancy [46]. This is also exacerbated by that fact that both physicians and patients feel there is limited time available for adequate and objective clinical evaluations and counselling. Therefore, a formal geriatric assessment may be a useful adjunct to identify which patients are at the highest risk of surgery when counseling patients on treatment options and which patients may benefit from prehabilitation [47].

This study has both limitations and strengths. One of the strengths is that we incorporated both physician and older women's opinions, which allowed us to identify areas where the two groups converged and diverged. Additionally, the qualitative nature of this study facilitated in-depth exploration of participant's opinions. Moreover, older women were interviewed at different time points from the initiation of their treatment, which allowed for varying perspectives regarding side effects and long-term impact of treatment decision. A limitation of this study is the homogeneity of both physicians and patients. Physician were all from a single, urban, academic institution with a predominant breast practice. Physicians treating older women in other centres may have different opinions from the ones expressed by this group. Patients were predominantly independent, Caucasian, English-speaking women who lived in a large urban area. This limits the applicability of this study to older women of diverse ethnic backgrounds and those who live in rural settings. Furthermore, volunteer bias exists, as the women who participated in our study all declined surgical therapy and are more likely to have strong views about their care. As a retrospective study, there may also be recall bias of events and details. Nonetheless, several themes were consistently triangulated across several women and physicians, which bolsters the face validity of the data.

\section{Conclusions}

The decision to avoid surgery in older women with invasive breast cancer is an intricate and individualized process. The common beliefs among physicians and patients is the desire to maintain quality of life and minimize harmful effects. Both groups identified the need for dedicated resources and more time spent with patients. Future studies should assess how dedicated resources affect decisionmaking process. It is also important to study a more heterogeneous population in terms of physician specialty and patient ethnicity. Ensuring a comprehensive understanding of the values and beliefs that influence a patient's treatment choice may facilitate shared decision-making and improve educational strategies for older women with breast cancer. 


\section{Abbreviations}

ER: estrogen receptor

IQR: interquartile range

M: months

MO, medical oncologist

NA, none available

PET: primary endocrine therapy

$\mathrm{RO}$, radiation oncologist

PR: progesterone receptor

$\mathrm{RT}$ : radiation therapy

SHSC: Sunnybrook Health Sciences Centre

SO: surgical oncologist

y: year

\section{Declarations}

Funding: None

Conflicts of interest/Competing interests: The authors declare that they have no conflict of interest.

Availability of data and material (data transparency): The datasets generated during and analysed during the current study are not publicly available because study participants did not consent for their data (original audio and transcripts) to be released.

Authors' contributions: All authors contributed to the study conception and design. Material preparation, data collection and analysis were performed by Fernando A. Angarita, Ethan Hoppe, Gary Ko, and Nicole Look Hong. The first draft of the manuscript was written by Fernando A. Angarita and all authors commented on previous versions of the manuscript. All authors read and approved the final manuscript.

Ethics approval: The interview guide and methodology for this study was approved by the Research Ethics Board at Sunnybrook Health Sciences Centre, Toronto, ON, Canada.

Consent to participate: Informed consent was obtained from all individual participants included in the study. 
Consent for publication: Study participants provided informed consent regarding publishing their data.

\section{References}

1. Jemal A, Tiwari RC, Murray T et al (2004) Cancer statistics 2004. CA Cancer J Clin 54:8-29

2. Louwman WJ, Vulto JCM, Verhoeven RHA et al (2007) Clinical epidemiology of breast cancer in the elderly. Eur J Cancer 43:2242-2252

3. Mandelblatt JS, Hadley J, Kerner JF et al (2000) Patterns of breast carcinoma treatment in older women: patient preference and clinical and physical influences. Cancer 89:561-573

4. Silliman RA, Troyan SL, Guadagnoli E et al (1997) The impact of age, marital status, and physicianpatient interactions on the care of older women with breast carcinoma. Cancer80:1326-1334

5. Hamaker ME, Schreurs WH, Uppelschoten JM et al (2009) Breast cancer in the elderly: retrospective study on diagnosis and treatment according to national guidelines. Breast $\mathrm{J} 15: 26-33$

6. Weggelaar I, Aben KK, Warlé MC et al (2011) Declined guideline adherence in older breast cancer patients: a population-based study in the Netherlands. Breast J 17:239-245

7. Angarita FA, Chesney T, Elser C, Mulligan AM, McCready DR, Escallon J (2015) Treatment patterns of elderly breast cancer patients at two Canadian cancer centres. Eur J Surg Oncol 41:625-634

8. Gopishetty S, Kota V, Guddati AK (2020) Age and race distribution in patients in phase III oncology clinical trials. Am J Transl Res 12:5977-5983

9. Hutchins LF, Unger JM, Crowley JJ et al (1999) Underrepresentation of patients 65 years of age or older in cancer-treatment trials. N Engl J Med 341:2061-2067

10. Lavelle K, Downing A, Thomas $\mathrm{J}$ et al (2012) Are lower rates of surgery amongst older women with breast cancer in the UK explained by co-morbidity? Br J Cancer 107:1175-1180

11. Kaur P, Santillan AA, McGuire K et al (2012) The surgical treatment of breast cancer in the elderly: a single institution comparative review of 5235 patients with 1028 patients $\geq 70$ years. Breast $\mathrm{J}$ 18:428-435

12. Velanovich V, Gabel M, Walker EM et al (2002) Causes for the undertreatment of elderly breast cancer patients: tailoring treatments to individual patients. J Am Coll Surg 194:8-13

13. Angarita FA, Elmi M, Zhang Y, Look Hong NJ (2018) Patient-reported factors influencing the treatment decision-making process of older women with non-metastatic breast cancer: a systematic review of qualitative evidence. Breast Cancer Res Treat 171:545-564

14. Ciambrone D (2006) Treatment decision-making among older women with breast cancer. J Women Aging 18:31-47

15. Husain LS, Collins K, Reed M, Wyld L (2008) Choices in cancer treatment: A qualitative study of the older women's (> 70 years) perspective. Psychooncology 17:410-416

16. Morgan JL, Burton M, Collins K, Lifford KJ, Robinson TG, Cheung KL et al (2015) The balance of clinician and patient input into treatment decision-making in older women with operable breast cancer. Psychooncology 24:1761-1766 
17. Burton M, Collins KA, Lifford KJ, Brain K, Wyld L, Caldon L et al (2015) The information and decision support needs of older women (> $75 \mathrm{yrs}$ ) facing treatment choices for breast cancer: A qualitative study. Psychooncology 24:878-884

18. Kreling B, Figeriredo MI, Sheppard VL, Mandelblatt JS (2006) A qualitative study of factors affecting chemotherapy use in older women with breast cancer: barriers, promoters, and implications for intervention. Psychooncology 15:1065-1076

19. Spencer L, Ritchie J, O'Connor W (2008) Chapter 8: analysis: practices, principles and processes. In: Ritchie JLJ (ed) Qualitative Research Practice. Sage Publications, London, pp 199-218

20. Ezer N, Veluswam RR, Mhango G et al (2015) Outcomes after Stereotactic Body Radiotherapy versus Limited Resection in Older Patients with Early-Stage Lung Cancer. J Thorac Oncol 10:1201-1206

21. Cassidy RJ, Patel RR, Zhang X et al (2017) Stereotactic Body Radiotherapy for Early-stage Non-smallcell Lung Cancer in Patients 80 Years and Older: A Multi-center Analysis. Clin Lung Cancer 18:551558

22. Schonberg M, Marcantonio E, Li D, Silliman R, Ngo L, McCarthy E (2010) Breast cancer among the oldest old: tumor characteristics, treatment choices, and survival. J Clin Oncol 28:2038-2045

23. Hack T, Degner L, Dyck D (1994) Relationship between preferences for decisional control and illness information among women with breast cancer: a quantitative and qualitative analysis. Soc Sci Med 39:279-289

24. Fallowfield L, Hall A, Maguire P, Baum M, A'Hern R (1994) A question of choice: results of a prospective 3-year follow-up study of women with breast cancer. Breast J 3:202-208

25. Angarita FA, Acuna SA, Cordeiro E, Elnahas A, Sutradhar S, Jackson T, Cil TD (2018) Thirty-day postoperative morbidity and mortality in elderly women with breast cancer: an analysis of the NSQIP database. Breast Cancer Res Treat 170:373-379

26. Carlson GW (2005) Total mastectomy under local anesthesia: the tumescent technique. Breast J 11:100-102

27. Santonastaso DP, de Chiara A, Russo E et al (2020) Thoracic paravertebral block and awake surgery: a prospective observational study. Tumori 26:300891620951626

28. Morgan JL, Collins K, Robinson TG et al (2015) Healthcare professionals' preferences for surgery or primary endocrine therapy to treat older women with operable breast cancer. Eur J Surg Oncol 41:1234-1242

29. Cordeiro E, Jackson T, Cil T (2016) Same-Day Major Breast Cancer Surgery is Safe: An Analysis of Short-Term Outcomes Using NSQIP Data. Ann Surg Oncol 23:2480-2486

30. Finlayson E, Zhao S, Boscardin WJ, Fries BE, Landefeld CS, Dudley RA (2012) Functional status after colon cancer surgery in elderly nursing home residents. J Am Geriatr Soc 60:967-973

31. Ronning B, Wyller TB, Jordhoy MS, Nesbakken A, Bakka A, Seljeflot I, Kristjansson S (2014) Frailty indicators and functional status in older patients after colorectal cancer surgery. J Geriatr Oncol $5: 26-32$ 
32. Amemiya T, Oda K, Ando M, Kawamura T, Kitagawa Y, Okawa Y, Fukata S (2007) Activities of daily living and quality of life of elderly patients after elective surgery for gastric and colorectal cancers. Ann Surg 246:222-228

33. Lawrence VA, Hazuda HP, Cornell JE, Pederson T, Bradshaw PT, Mulrow CD, Page CP (2004)

Functional independence after major abdominal surgery in the elderly. J Am Coll Surg 199:762-772

34. Lee DD, Wasson M, Hallock JL et al (2019) Return to Baseline Functional Status in Older Women Undergoing Surgery for Pelvic Organ Prolapse. Female Pelvic Med Reconstr Surg. doi:

10.1097/SPV.0000000000000772. Epub ahead of print. PMID: 31490847

35. Amir E, Seruga B, Niraula S, Carlsson L, Ocaña A (2011) Toxicity of adjuvant endocrine therapy in postmenopausal breast cancer patients: a systematic review and meta-analysis. J Natl Cancer Inst 103:1299-1309

36. Puts MTE, Tu HA, Tourangeau A et al (2014) Factors influencing adherence to cancer treatment in older adults with cancer: a systematic review. Ann Oncol 25:564-577

37. van de Water W, Bastiaannet E, Hille ET et al (2012) Age-specific nonpersistence of endocrine therapy in postmenopausal patients diagnosed with hormone receptor-positive breast cancer: a TEAM study analysis. Oncologist 17:55-63

38. Hind D, Wyld L, Reed MW (2007) Surgery, with or without tamoxifen, vs tamoxifen alone for older women with operable breast cancer: Cochrane review. $\mathrm{Br} J$ Cancer 96:1,025-021,029

39. Cuzick J, Sestak I, Baum M et al (2010) Effect of anastrozole and tamoxifen as adjuvant treatment for early-stage breast cancer: 10-year analysis of the ATAC trial. Lancet Oncol 11:1135-1141

40. Regan MM, Neven P, Giobbie-Hurder A et al (2011) Assessment of letrozole and tamoxifen alone and in sequence for postmenopausal women with steroid hormone receptor-positive breast cancer: the BIG 1-98 randomised clinical trial at 8.1 years median follow-up. Lancet Oncol 12:1101-1108

41. Eiermann W, Paepke S, Appfelstaedt J et al (2001) Preoperative treatment of postmenopausal breast cancer patients with letrozole: a randomized doubleblind multicenter study. Ann Oncol 12:15271532

42. Riemsma R, Forbes CA, Kessels A et al (2010) Systematic review of aromatase inhibitors in the firstline treatment for hormone sensitive advanced or metastatic breast cancer. Breast Cancer Res Treat 123:9-24

43. Sowerbutts AM, Griffiths J, Todd C, Lavelle K (2015) Why are older women not having surgery for breast cancer? A qualitative study. Psychooncology 24:1036-1042

44. Morrison R (1994) Patients' sense of completion. BMJ308:1722-1722

45. Thomas R, Pieri A, Cain H (2017) A systematic review of generic and breast cancer specific life expectancy models in the elderly. Eur J Surg Oncol 43:1816-1827

46. Wylie S, Ravichandran D (2013) A UK national survey of breast surgeons on primary endocrine therapy of early operable breast cancer. Ann R Coll Surg Engl 95:353-356 
47. Soto-Perez-de-Celis E, Li D, Yuan Y, Lau YM, Hurria A (2018) Functional versus chronological age: geriatric assessments to guide decision making in older patients with cancer. Lancet Oncol 19:305316

\section{Tables}


Table 1

Patient characteristics

\begin{tabular}{|c|c|}
\hline Variable & $\mathbf{N}^{1}$ \\
\hline \multicolumn{2}{|l|}{ Demographics } \\
\hline Age at time of diagnosis (y), median (IQR) & $\begin{array}{l}84(75- \\
89)\end{array}$ \\
\hline Time between diagnosis and interview $(\mathrm{m})$, median (IQR) & $\begin{array}{l}22(4- \\
51)\end{array}$ \\
\hline $\begin{array}{l}\text { Marital status } \\
\text { Single } \\
\text { Married } \\
\text { Widowed } \\
\text { Divorced } \\
\text { Not specified }\end{array}$ & $\begin{array}{l}2 \\
2 \\
5 \\
1 \\
1\end{array}$ \\
\hline $\begin{array}{l}\text { Race } \\
\text { White } \\
\text { Asian }\end{array}$ & $\begin{array}{l}10 \\
1\end{array}$ \\
\hline \multicolumn{2}{|l|}{ Past medical history } \\
\hline $\begin{array}{l}\text { Comorbidities }^{2} \\
\text { Cardiac } \\
\text { Respiratory } \\
\text { Gastrointestinal } \\
\text { Endocrine } \\
\text { Musculoskeletal } \\
\text { Neurologic } \\
\text { Ophthalmologic } \\
\text { Psychiatric } \\
\text { Other }^{3}\end{array}$ & $\begin{array}{l}11 \\
2 \\
4 \\
7 \\
5 \\
6 \\
4 \\
4 \\
3\end{array}$ \\
\hline Number of comorbidities per patient, median (IQR) & $5(2-6)$ \\
\hline \multicolumn{2}{|l|}{ Current breast cancer } \\
\hline $\begin{array}{l}\text { Method of detection of breast cancer } \\
\text { Imaging detected } \\
\text { Palpable mass } \\
\text { Ulcerated mass }\end{array}$ & $\begin{array}{l}2 \\
7 \\
2\end{array}$ \\
\hline $\begin{array}{l}\text { Clinical TNM } \\
\text { T2N0M0 } \\
\text { T2N1M0 } \\
\text { T3N0M0 } \\
\text { T3N1M0 } \\
\text { T4N0M0 } \\
\text { T4N1M0 }\end{array}$ & $\begin{array}{l}5 \\
1 \\
2 \\
1 \\
1 \\
1\end{array}$ \\
\hline $\begin{array}{l}\text { Tumour histology } \\
\text { Invasive ductal carcinoma } \\
\text { Invasive lobular carcinoma }\end{array}$ & $\begin{array}{l}9 \\
2\end{array}$ \\
\hline
\end{tabular}




\begin{tabular}{|c|c|}
\hline Variable & $\mathbf{N}^{1}$ \\
\hline $\begin{array}{l}\text { Hormone receptor status } \\
\text { ER+/PR+/HER2/neu - } \\
\text { ER+/PR- /HER2/neu - } \\
\text { ER- /PR-/HER2/neu - }\end{array}$ & $\begin{array}{l}8 \\
2 \\
1\end{array}$ \\
\hline Breast cancer treatment & \\
\hline $\begin{array}{l}\text { Initial breast cancer treatment } \\
\text { Aromatase inhibitor } \\
\text { Radiation therapy } \\
\text { None }\end{array}$ & $\begin{array}{l}8 \\
2 \\
1\end{array}$ \\
\hline
\end{tabular}


Table 2

Physician- and patient-reported factors that influence the decision-making of older women with breast cancer

\begin{tabular}{|c|c|c|c|c|}
\hline Concept & $\begin{array}{l}\text { Physicians' } \\
\text { Beliefs }\end{array}$ & Demonstrative Quotes & $\begin{array}{l}\text { Patient's } \\
\text { Belief }\end{array}$ & $\begin{array}{l}\text { Demonstrative } \\
\text { Quotes }\end{array}$ \\
\hline \multicolumn{5}{|l|}{ CONVERGENT } \\
\hline Cosmesis & $\begin{array}{l}\text { Reconstruction } \\
\text { is not } \\
\text { discussed } \\
\text { Elderly women } \\
\text { do not care } \\
\text { about } \\
\text { cosmesis or } \\
\text { impact of } \\
\text { treatment on } \\
\text { sexuality }\end{array}$ & $\begin{array}{l}\text { "They don't care if their } \\
\text { breasts don't match so } \\
\text { well. They don't bother } \\
\text { putting nipples on and } \\
\text { things like that." (MO1) }\end{array}$ & $\begin{array}{l}\text { Cosmetic } \\
\text { result does } \\
\text { not affect } \\
\text { decision- } \\
\text { making }\end{array}$ & $\begin{array}{l}\text { "I live alone. } \\
\text { Nobody is } \\
\text { seeing me. No, } \\
\text { it wasn't body } \\
\text { image at all." } \\
(\mathrm{P}-001)\end{array}$ \\
\hline $\begin{array}{l}\text { Treatment } \\
\text { characteristics/ } \\
\text { Fear of } \\
\text { Anesthesia }\end{array}$ & $\begin{array}{l}\text { Factors } \\
\text { women } \\
\text { generally cite } \\
\text { include } \\
\text { easiness of } \\
\text { compliance, } \\
\text { risk of side } \\
\text { effects, and } \\
\text { duration }\end{array}$ & $\begin{array}{l}\text { "Or the lady that's like, } \\
\text { I'm } 80 \text { years old and I } \\
\text { don't want to come here } \\
\text { for five weeks. I'm going } \\
\text { to get tired..." (RO4) } \\
\text { "Often they don't think } \\
\text { they can get through an } \\
\text { operation and a general } \\
\text { anesthetic..." (SO1) }\end{array}$ & $\begin{array}{l}\text { Beliefs } \\
\text { regarding side } \\
\text { effects of } \\
\text { anesthesia } \\
\text { Fear of extent } \\
\text { and duration } \\
\text { of surgery }\end{array}$ & $\begin{array}{l}\text { “I just felt like I } \\
\text { didn't want to } \\
\text { have } \\
\text { anaesthetic. I'm } \\
\text { older and I } \\
\text { know people } \\
\text { who've had } \\
\text { surgery and } \\
\text { they haven't } \\
\text { been the same } \\
\text { since." (P-010) } \\
\text { "If I remember } \\
\text { all this, it was } \\
\text { either a } \\
\text { mastectomy ... } \\
\text { well, first of all, } \\
\text { the medication, } \\
\text { a mastectomy, } \\
\text { and I'm not sure } \\
\text { if they offered } \\
\text { the } \\
\text { lumpectomy or } \\
\text { I said couldn't } \\
\text { we do a } \\
\text { lumpectomy. } \\
\text { Because I don't } \\
\text { know, I just } \\
\text { didn't really } \\
\text { want a big } \\
\text { surgery." (P- } \\
011)\end{array}$ \\
\hline
\end{tabular}




\begin{tabular}{|c|c|c|c|c|}
\hline Concept & $\begin{array}{l}\text { Physicians' } \\
\text { Beliefs }\end{array}$ & Demonstrative Quotes & $\begin{array}{l}\text { Patient's } \\
\text { Belief }\end{array}$ & $\begin{array}{l}\text { Demonstrative } \\
\text { Quotes }\end{array}$ \\
\hline $\begin{array}{l}\text { Patient } \\
\text { characteristics }\end{array}$ & $\begin{array}{l}\text { Chronologic } \\
\text { age becomes } \\
\text { an issue in } \\
\text { women over } \\
80 \text { years old } \\
\text { Comorbidities } \\
\text { and functional } \\
\text { status } \\
\text { increase risk } \\
\text { of } \\
\text { complications }\end{array}$ & $\begin{array}{l}\text { "I start changing my } \\
\text { surgical approach is } \\
\text { more in women in their } \\
80 \text { s or if women have a } \\
\text { lot of comorbidities and } \\
\text { they're in their } 70 \text { s." } \\
\text { (SO1) }\end{array}$ & $\begin{array}{l}\text { Chronologic } \\
\text { age as a } \\
\text { moderator of } \\
\text { decision } \\
\text { making } \\
\text { Self- } \\
\text { awareness of } \\
\text { comorbidities } \\
\text { and life } \\
\text { expectancy }\end{array}$ & $\begin{array}{l}\text { "I think if I was } \\
\text { young, I would } \\
\text { have opted for } \\
\text { the surgery." } \\
\text { (P-001) } \\
\text { "Maybe } 30 \\
\text { years ago I } \\
\text { would have } \\
\text { said, sure, go } \\
\text { ahead. But I } \\
\text { just wanted to } \\
\text { know if there } \\
\text { were } \\
\text { alternatives, } \\
\text { and there was, } \\
\text { you see, there } \\
\text { was, and they } \\
\text { all decided that } \\
\text { with my age, } \\
\text { my willingness } \\
\text { to go ahead } \\
\text { with this, so } \\
\text { that was fine." } \\
\text { (P-006) }\end{array}$ \\
\hline $\begin{array}{l}\text { Impact on quality } \\
\text { of life/ } \\
\text { Independence }\end{array}$ & $\begin{array}{l}\text { Women } \\
\text { prioritize } \\
\text { quality over } \\
\text { quantity } \\
\text { Maintaining } \\
\text { current } \\
\text { lifestyle is a } \\
\text { priority }\end{array}$ & $\begin{array}{l}\text { "There are women who } \\
\text { say you know what, this } \\
\text { is like four months, it's } \\
\text { December and I want to } \\
\text { get to Florida this year, } \\
\text { forget it." (MO1) }\end{array}$ & $\begin{array}{l}\text { Desire to } \\
\text { maintain } \\
\text { independent } \\
\text { lifestyle } \\
\text { Choosing } \\
\text { quality over } \\
\text { quantity of life }\end{array}$ & $\begin{array}{l}\text { "I think Dr.- } \\
\text { said that it } \\
\text { would take } \\
\text { about three } \\
\text { months for me } \\
\text { to get over the } \\
\text { surgery. I really } \\
\text { value my life, } \\
\text { and I hate to } \\
\text { give up three } \\
\text { months of } \\
\text { hanging } \\
\text { around, not } \\
\text { doing } \\
\text { anything." (P- } \\
\text { 006) } \\
\text { "I said quality } \\
\text { of life is more } \\
\text { important than } \\
\text { quantity." (P- } \\
011 \text { ) }\end{array}$ \\
\hline
\end{tabular}




\begin{tabular}{|c|c|c|c|c|}
\hline Concept & $\begin{array}{l}\text { Physicians' } \\
\text { Beliefs }\end{array}$ & Demonstrative Quotes & $\begin{array}{l}\text { Patient's } \\
\text { Belief }\end{array}$ & $\begin{array}{l}\text { Demonstrative } \\
\text { Quotes }\end{array}$ \\
\hline $\begin{array}{l}\text { Previous } \\
\text { experience/ } \\
\text { Others' } \\
\text { recommendations }\end{array}$ & $\begin{array}{l}\text { Prior negative } \\
\text { personal or } \\
\text { family } \\
\text { experience } \\
\text { affects } \\
\text { decisions } \\
\text { Older women } \\
\text { grew up in the } \\
\text { paternalism } \\
\text { era } \\
\text { Decisions may } \\
\text { be deferred to } \\
\text { relatives } \\
\text { Women trust } \\
\text { their family } \\
\text { members and } \\
\text { healthcare } \\
\text { team }\end{array}$ & $\begin{array}{l}\text { "The two things that I } \\
\text { would say are that } \\
\text { they've had either } \\
\text { personal or friends or } \\
\text { family experiences with } \\
\text { medicine with } \\
\text { treatments and } \\
\text { sometimes they've seen } \\
\text { negative things happen } \\
\text { in terms of side-effects } \\
\text { and want to avoid that } \\
\text { personally." (RO1) } \\
\text { "But, in my experience, } \\
\text { most of the older } \\
\text { women are quite... } \\
\text { they're of that era where } \\
\text { you just do what the } \\
\text { doctor says. You don't } \\
\text { necessarily challenge it } \\
\text { as much." (RO4) }\end{array}$ & $\begin{array}{l}\text { Other people's } \\
\text { and personal } \\
\text { experience } \\
\text { influenced } \\
\text { their opinion } \\
\text { about } \\
\text { treatment }\end{array}$ & $\begin{array}{l}\text { “So, I'm in } \\
\text { pretty good } \\
\text { health, at least I } \\
\text { was until I got } \\
\text { this lump. I did } \\
\text { have a lump in } \\
\text { 1982, a } \\
\text { malignant } \\
\text { lump. It was } \\
\text { removed and I } \\
\text { didn't have } \\
\text { anything. I } \\
\text { didn't want } \\
\text { anything. And } \\
\text { l've lived all } \\
\text { these years } \\
\text { with no } \\
\text { treatment." (P- } \\
\text { 001) } \\
\text { "Well, I knew I } \\
\text { didn't ever want } \\
\text { chemo because } \\
\text { I've gone } \\
\text { through it with } \\
\text { too many } \\
\text { friends and } \\
\text { relatives and } \\
\text { my sister and I } \\
\text { think it's a } \\
\text { brutal way of } \\
\text { treating the } \\
\text { body." (P-012) }\end{array}$ \\
\hline
\end{tabular}




\begin{tabular}{|c|c|c|c|c|}
\hline Concept & $\begin{array}{l}\text { Physicians' } \\
\text { Beliefs }\end{array}$ & Demonstrative Quotes & $\begin{array}{l}\text { Patient's } \\
\text { Belief }\end{array}$ & $\begin{array}{l}\text { Demonstrative } \\
\text { Quotes }\end{array}$ \\
\hline $\begin{array}{l}\text { Lack of resources } \\
\text { specific to older } \\
\text { women }\end{array}$ & $\begin{array}{l}\text { Managing } \\
\text { elderly women } \\
\text { takes time } \\
\text { Proper } \\
\text { assessments } \\
\text { are complex } \\
\text { Multiple issues } \\
\text { need to be } \\
\text { considered }\end{array}$ & $\begin{array}{l}\text { "It's, unfortunately, } \\
\text { unrealistic that the } \\
\text { physician in a busy } \\
\text { clinic is going to do all } \\
\text { that stuff and take care } \\
\text { of the cancer, and take } \\
\text { care of all the other } \\
\text { stuff." (RO4) }\end{array}$ & $\begin{array}{l}\text { Desire for } \\
\text { more time, } \\
\text { information, } \\
\text { or allied } \\
\text { health care } \\
\text { workers } \\
\text { Desire for } \\
\text { support } \\
\text { groups }\end{array}$ & $\begin{array}{l}\text { "I know they } \\
\text { have to rush to } \\
\text { somebody else, } \\
\text { so it's not a } \\
\text { place to have a } \\
\text { lengthy } \\
\text { conversation. I } \\
\text { guess that's } \\
\text { where a nurse } \\
\text { or social worker } \\
\text { might come in } \\
\text { handy." (P- } \\
011) \\
\text { "You don't get } \\
\text { very much } \\
\text { explanation. } \\
\text { You could } \\
\text { always use } \\
\text { more." (P-009) } \\
\text { "It would be } \\
\text { nice to talk to } \\
\text { other women } \\
\text { that went } \\
\text { through the } \\
\text { same." (P-011) } \\
\text { "The doctors } \\
\text { are so busy, I } \\
\text { think they could } \\
\text { spend a bit } \\
\text { more time } \\
\text { discussing it." } \\
\text { (P-011) }\end{array}$ \\
\hline \multicolumn{5}{|l|}{ DIVERGENT } \\
\hline Survival benefit & $\begin{array}{l}\text { Marginal } \\
\text { survival } \\
\text { benefit for } \\
\text { women with } \\
\text { limited life } \\
\text { span and for } \\
\text { those who do } \\
\text { not want to } \\
\text { live longer }\end{array}$ & $\begin{array}{l}\text { "Patients will say if this } \\
\text { is going to help three or } \\
\text { four out of a hundred } \\
\text { women and not help the } \\
\text { rest, I'm not going } \\
\text { through these side } \\
\text { effects, forget it." (M01) }\end{array}$ & $\begin{array}{l}\text { Marginal } \\
\text { benefit given } \\
\text { "benign" } \\
\text { characteristics }\end{array}$ & $\begin{array}{l}\text { "I'm pretty old, I } \\
\text { never figured ... } \\
\text { this thing } \\
\text { probably } \\
\text { doesn't grow } \\
\text { very much, } \\
\text { from what I've } \\
\text { heard over the } \\
\text { years. I thought } \\
\text { that maybe I } \\
\text { could just live } \\
\text { with it." (P- } \\
006 \text { ) }\end{array}$ \\
\hline
\end{tabular}




\begin{tabular}{|c|c|c|c|c|}
\hline Concept & $\begin{array}{l}\text { Physicians' } \\
\text { Beliefs }\end{array}$ & Demonstrative Quotes & $\begin{array}{l}\text { Patient's } \\
\text { Belief }\end{array}$ & $\begin{array}{l}\text { Demonstrative } \\
\text { Quotes }\end{array}$ \\
\hline Cultural barriers & $\begin{array}{l}\text { Language } \\
\text { barriers make } \\
\text { treatment } \\
\text { discussion } \\
\text { difficult } \\
\text { Patient's } \\
\text { culture } \\
\text { determines the } \\
\text { decision- } \\
\text { making model }\end{array}$ & $\begin{array}{l}\text { "Similarly, someone } \\
\text { who's very fit and has a } \\
\text { long potential life } \\
\text { expectancy, but who } \\
\text { somehow has cultural } \\
\text { views that if you get a } \\
\text { diagnosis of cancer } \\
\text { then there's no point in } \\
\text { treating it because the } \\
\text { outcome is } \\
\text { predetermined, then } \\
\text { those patients, I would } \\
\text { probably spend a little } \\
\text { more time with." (SO2) }\end{array}$ & NA & NA \\
\hline Pain & NA & NA & $\begin{array}{l}\text { Pain as a } \\
\text { determinant } \\
\text { of an ideal } \\
\text { treatment }\end{array}$ & $\begin{array}{l}\text { "Yes, very } \\
\text { happy [with } \\
\text { radiation] } \\
\text { because there's } \\
\text { no pain and it } \\
\text { work for me." } \\
\text { (P-004) } \\
\text { "I'm not } \\
\text { surgically } \\
\text { inclined. I have } \\
\text { friends who oh } \\
\text { l've got this and } \\
\text { l've to get it } \\
\text { taken off, oh } \\
\text { I've got a pain } \\
\text { and I think l've } \\
\text { got, and they're } \\
\text { running to the } \\
\text { doctor every } \\
\text { two minutes } \\
\text { and l've never } \\
\text { been like that." } \\
\text { (P-008) }\end{array}$ \\
\hline
\end{tabular}




\begin{tabular}{|c|c|c|c|c|}
\hline Concept & $\begin{array}{l}\text { Physicians' } \\
\text { Beliefs }\end{array}$ & Demonstrative Quotes & $\begin{array}{l}\text { Patient's } \\
\text { Belief }\end{array}$ & $\begin{array}{l}\text { Demonstrative } \\
\text { Quotes }\end{array}$ \\
\hline Satisfaction & NA & NA & $\begin{array}{l}\text { Satisfaction } \\
\text { with } \\
\text { healthcare } \\
\text { system } \\
\text { Satisfaction } \\
\text { with lack of } \\
\text { treatment side } \\
\text { effects } \\
\text { Satisfaction } \\
\text { with lack of } \\
\text { interruption of } \\
\text { independent } \\
\text { lifestyle }\end{array}$ & $\begin{array}{l}\text { "I felt that I was } \\
\text { treated with } \\
\text { great respect } \\
\text { from the team } \\
\text { at --. I never felt } \\
\text { that ageism } \\
\text { came into it } \\
\text { with them, and } \\
\text { that's a very } \\
\text { real thing with } \\
\text { other people in } \\
\text { other } \\
\text { circumstances." } \\
\text { (P-003) } \\
\text { "Well, so far I've } \\
\text { had no side-- } \\
\text { effects. They } \\
\text { told me what } \\
\text { side-effects } \\
\text { there might be, } \\
\text { but I've had no } \\
\text { side-effects. I've } \\
\text { been lucky." (P- } \\
001)\end{array}$ \\
\hline $\begin{array}{l}\text { Amount of social } \\
\text { support }\end{array}$ & $\begin{array}{l}\text { Transportation } \\
\text { needs impact } \\
\text { decision to } \\
\text { accept chemo- } \\
\text { and radiation } \\
\text { therapy }\end{array}$ & $\begin{array}{l}\text { "Although often they're } \\
\text { left for long periods of } \\
\text { time which, if they're } \\
\text { not the only one in a } \\
\text { ride, if they're ride } \\
\text { sharing with a group, } \\
\text { they may be sitting for } \\
\text { hours, so that's not } \\
\text { always great." (MO2) }\end{array}$ & $\begin{array}{l}\text { Having friends } \\
\text { and family as } \\
\text { a support in } \\
\text { the process }\end{array}$ & $\begin{array}{l}\text { "Yes, I get some } \\
\text { good support } \\
\text { from my family } \\
\text { and from the } \\
\text { doctors. } \\
\text { They've gone } \\
\text { along with any } \\
\text { treatment I } \\
\text { might want to } \\
\text { have or } \\
\text { anything." (P- } \\
001) \\
\text { "My family is } \\
\text { all gone. I have } \\
\text { a colleague } \\
\text { who works in } \\
\text { the office and I } \\
\text { have several } \\
\text { friends like } \\
\text { that." (P-009) }\end{array}$ \\
\hline
\end{tabular}




\begin{tabular}{|lllll|}
\hline Concept & $\begin{array}{l}\text { Physicians' } \\
\text { Beliefs }\end{array}$ & Demonstrative Quotes & $\begin{array}{l}\text { Patient's } \\
\text { Belief }\end{array}$ & $\begin{array}{l}\text { Demonstrative } \\
\text { Quotes }\end{array}$ \\
\hline Empowerment & NA & NA & $\begin{array}{l}\text { Patient felt } \\
\text { empowered to } \\
\text { participate in } \\
\text { the decision- } \\
\text { making } \\
\text { process }\end{array}$ & $\begin{array}{l}\text { "You know I did } \\
\text { momework } \\
\text { and found out } \\
\text { what was the } \\
\text { best route to go } \\
\text { and then made } \\
\text { the decision } \\
\text { which way I } \\
\text { wanted to go." } \\
\text { (P-008) }\end{array}$ \\
\hline $\begin{array}{l}\text { Caretaker } \\
\text { responsibilities }\end{array}$ & $\begin{array}{l}\text { Women may } \\
\text { take care of } \\
\text { other family } \\
\text { members, } \\
\text { especially } \\
\text { husbands } \\
\text { Women put } \\
\text { other's needs } \\
\text { first }\end{array}$ & $\begin{array}{l}\text { "And they decline } \\
\text { radiation treatment } \\
\text { because they don't feel } \\
\text { comfortable leaving } \\
\text { their partner who has } \\
\text { dementia or has some } \\
\text { illness at home alone..." } \\
\text { (RO1) }\end{array}$ & NA & NA \\
\hline
\end{tabular}

\section{Figures}






\section{Figure 1}

Study design and interview development process. 


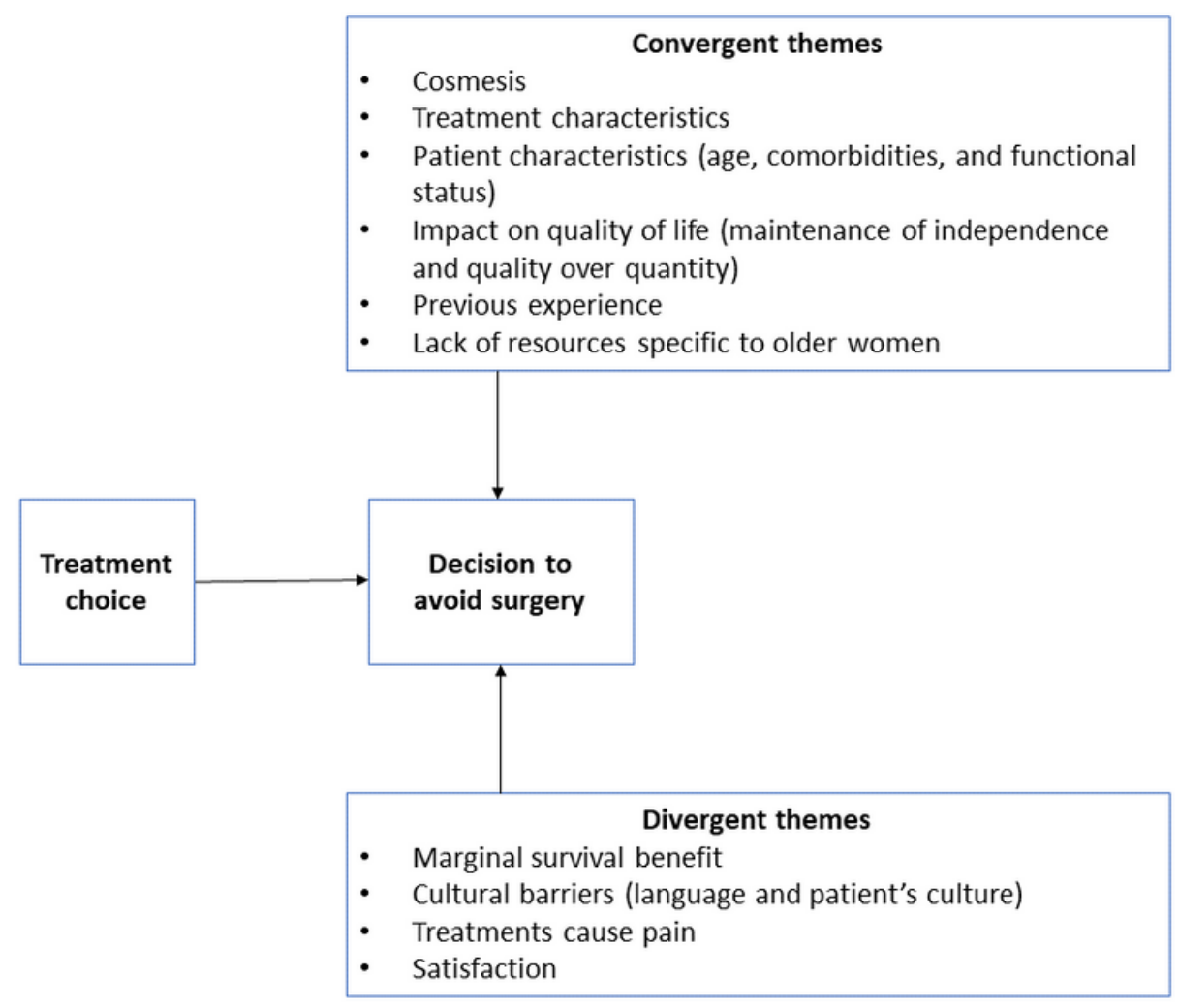

Figure 2

Conceptual theory model 